\title{
Owners' Perception towards Sustainable Housing Affordability in Kuching, Sarawak
}

\author{
Rosli Said $^{1 \star}$, Rohayu Ab. Majid², Md Nasir Daud ${ }^{3}$, Zulkifli Esha ${ }^{4}$ and Muhammad Najib \\ Razali $^{5}$ \\ ${ }^{1,3,4}$ Centre for Sustainable Urban Planning and Real Estate (SUPRE), Faculty of Built \\ Environment, University of Malaya, 50603 Kuala Lumpur, Malaysia \\ ${ }^{2}$ Centre for Studies of Real Estate Management, Faculty of Architecture, Planning \& \\ Surveying, Universiti Teknologi Mara, 40450 Shah Alam, Selangor, Malaysia. \\ ${ }^{5}$ Faculty of Geoinformation and Real Estate, Universiti Teknologi Malaysia, 81310 Johor \\ Bahru, Johor.
}

*rosli_alambina@um.edu.my,

Since late 1980s, Malaysia has been experiencing accelerated development in its housing sector as a result of rapid urbanisation and economic growth. A similar trend has prevailed in Sarawak where housing has thrived owing to growing market and active supply-demand dynamics. However, the cosmic increase in housing prices since 2012 has raised serious concerns among researchers with regard to how sustainable housing is in this country. Price spiral has led to an acute shortage of housing affordable to the middle-income group. Therefore, alternatives for dealing with housing affordability have to be worked on in steering the future direction of housing in the country. In dealing with such issue, a set of criteria encompassing social, economic and environmental influences would need to be identified and evaluated to determine the best alternative or option available for any particular area. A study was conducted on the city of Kuching and its hinterland. COPRAS was used. The results indicate that an area with a high degree of utility conforms best to sustainable housing affordability while the area with a lower degree of utility performs poorly in this respect. The originality of this research has contributed to new literature in dealing with sustainable housing affordability in Malaysia, particularly in the state of Sarawak.

Keywords: Sustainability, COPRAS, MCDM, sustainable housing, housing affordability

\section{INTRODUCTION}

One of the principal aims of The National Malaysian Housing Policy is to provide housing that is affordable and of acceptable quality for each household. Laws relating to sustainable development through physical, economic, social and environmental well-being have been in existence to deal with housing development in Malaysia (Othman \& Alias, 2011). As a concept, sustainable development is new to take hold in Malaysia and remains open to debate. However, this has not stopped housing developers from leveraging on the idea of sustainability when it comes to marketing their houses (Abidin, 2010). In order to harmonise the economic development, social integration and environmental protection, the authorities have put in place several initiatives to minimise the perverse effect of economic growth on the environment.
In the housing policy of any country, much attention has been focussed on housing affordability (Ankhi \& Joy, 2013; Zyed et al., 2016) and housing market (Majid and Said, 2013). Ankhi \& Joy (2013) assessed variations in basic and composite housing affordability in India and called for immediate government intervention on both ownership and rental housing development to the low-to-middle income population. Locally, Zyed et al. (2016) found that young households often have to compete with other income groups for homeownership on account of very limited supply of housing affordable to them in the market. Majid and Said (2013) identified the impact of real estate cycle on houses priced beyond the affordable limit. However, none of the local studies has explicitly focussed on the sustainable aspect of housing affordability.

Thus the primary objective of this paper is to identify areas with existing affordable units at the time of purchase and affordable rent for 
the rental market that can sustain and enhance the quality of life as the area to live in or rent, respectively. For this purpose, the Multiattribute Complex Proportional Assessment (COPRAS) method (one of the frameworks of Multi-Criteria Decision Making) will be employed by establishing a set of criteria for sustainable housing affordability. In order to gain further insight into sustainable housing affordability, this paper is organised as follows. First, relevant literature incorporates the concept of sustainability, sustainable housing affordability and factors influencing them. Then the discussion on the criteria of sustainable housing affordability and the tools used in assessing sustainability follows. Thereafter, analysis and conclusion of the paper are presented and discussed.

\section{LITERATURE REVIEW}

\subsection{Defining Sustainability}

The term sustainability has been defined as "development that meets the needs of the present without compromising the ability of future generations to meet their own needs" (Brundtland, 1996). However, it can be interpreted in different ways. Debates among researchers in dealing with the vague definition of sustainability will impede the progress of making the concept of sustainability operational (Beck and Cummings, 1996). The uniqueness of terminology used by researchers has made this topic so much interesting. The lack of authoritative definition allows it to embody broad concepts which, in turn, bestow upon it the ability to be flexible. Therefore, the term sustainability can be adopted in any situation to suit local context.

In the most direct definition, sustainability can be referred to the observation of balancing between the three concepts namely economic development, social equity and environmental protection (Drexhage \& Murphy, 2010; Said et al., 2016; Mohamad \& Ahmad, 2016). In a broader aspect, sustainability would also include social (health and equity), human values (freedom, tolerance and respect for nature) and ecological (climate, air quality and land-use efficiency) attributes (Kates et al., 2005; Islam, 1996; Van Vliet, 1996).

In dealing with the built environment, sustainability revolves around the idea of being the persistence of particular necessary and desired attributes of people, communities and organisation surrounding the eco-system (Hardi and Zidan, 1997). This idea expresses the interrelationship between people and their surroundings. In addition, sustainable building can be referred to as facilities formed by sustainable construction for the sole objective of enhancing health, improving resources efficiency and limiting the detrimental effect of the built environment on the ecological system (Kibert, 2004).

\subsection{Defining Sustainable Housing Affordability}

Medineckiene et al. $\left(2010_{\mathrm{a}, \mathrm{b}}\right)$ considered the current economic, social and built environment situations in defining sustainable housing affordability. Maliene and Malys (2009) further elucidate sustainable housing as one that is well available, of high quality, economical, ecological, aesthetical in design, comfortable, and cosy. Sustainable housing should also consider cost-efficiency with good energy, waste, and water management.

The foundation of 'sustainable housing affordability' was introduced by Mulliner and Maliene (2011) where an initial system of criteria for sustainable housing affordability has been established. Mulliner and Maliene (2011) further argued that housing affordability should not be isolated from other criteria such as location, social, environment and economic sustainability of the housing. In addition, affordable housing is not merely about cheap homes, but must incorporate other factors as well (Mulliner and Maliene, 2011).

Mulliner et al. (2013) suggested that a low demand for housing units is partly due to the location that is not well connected to jobs, highquality services and infrastructure. Therefore, a major backbone of housing design and a fundamental dimension of housing quality should deal with sustainability aspects of the units (Morgan \& Talbot, 2001; Mohamad \& Ahmad, 2016). Further pre-requisite for sustainable housing affordability include physical attributes, community involvement and the challenge of getting the right 'mix' (Turcu, 2012). Iman (2006) suggests similar view whereby sustainable housing must be environmentally appropriate, financially viable, socially acceptable and technically feasible. The term 'environmentally appropriate' refers to human or its inherent value (Payne and Raiborn, 2001). 


\subsection{Criteria for Sustainable Housing Affordability}

Numerous researchers have discussed sustainable and affordable housing. The implementation of environmental sustainability in affordable housing goes against the primary objective of providing cheap houses (Yates, 2008). The high cost of implementing sustainability will usually be passed on into housing costs.

A framework for determining the criteria for sustainability has been developed by Pullen et al., (2010). The sustainability criteria set by Pullen et al., (2010) consist of nine essential elements and sub-elements. The essential elements are efficiency (energy, water), construction (materials, methods), procurement (government, private, public-private partnership), affordability (purchase or rent), desirability, dwelling sizes, appropriate density (low, medium, high), adaptability and social acceptability. Mcalpine \& Birnie (2007) further introduce a 2-tier system of sustainability consisting of a headline and strategic indicators to monitor the quantifiable sustainability themes. The indicators include, among other things, the quality of housing, environmental quality, land use, household and commercial waste and local transportation.

This paper utilises a combination of literature review and semi-structured interviews to determine the relative importance of each criterion. The concept established in other countries may be ideal to be implemented in Malaysia althought they are different in culture, preferences and attitude. Using the work of Mulliner and Maliene (2011) as a base, this paper adds other criteria to firm up the study. The final list of 26 factors tailored to the study was developed (Table 1).

Table 1: Selected Criteria for Sustainable Housing Affordability in Malaysia

\begin{tabular}{|l|l|l|}
\hline \multicolumn{2}{|l|}{ Sustainable Housing Affordability Factors } & \multicolumn{1}{c|}{ Sources } \\
\hline F1 & House Price & $\begin{array}{l}\text { (Aziz } \text { et al., 2010; Burke } \text { et al., 2007; Mulliner \& } \\
\text { Maliene, 2011) }\end{array}$ \\
\hline F2 & House Type & $\begin{array}{l}\text { (Hurtubia } \text { et al., 2010; Mohamad \& Ahmad, } \\
\text { 2016) }\end{array}$ \\
\hline F3 & House Finishes & (Fierro et al., 2009) \\
\hline F4 & House Design & (Fierro et al., 2009; Mohamad \& Ahmad, 2016) \\
\hline F5 & Position of the House in Layout Plan & (Hurtubia et al., 2010) \\
\hline F6 & Size of Built-up Area & (Fierro et al., 2009) \\
\hline F7 & Size of Land Area & (Fierro et al., 2009) \\
\hline F8 & Age of the Unit & (Fierro et al., 2009) \\
\hline F9 & Topography & (Fierro et al., 2009) \\
\hline F10 & Property Interest & (Lu, 2002; Saunders, 1990) \\
\hline F11 & Near to Commercial Area & (Mulliner \& Maliene, 2011; Samuels, 2004) \\
\hline F12 & Near to Hospitals & (Mulliner \& Maliene, 2011; Zhu et al., 2006) \\
\hline F13 & Near to Post Office & (Said et. al, 2016) \\
\hline F14 & $\begin{array}{l}\text { Near to Recreation Area \& Public } \\
\text { Space }\end{array}$ & $\begin{array}{l}\text { (Isalou } \text { et al., 2014; Mulliner \& Maliene, 2011; } \\
\text { Yusuf \& Resosurdarmo, 2009) }\end{array}$ \\
\hline F15 & Near to Transportation & $\begin{array}{l}\text { (Australian Conservation Foundation, 2008; } \\
\text { Mulliner \& Maliene, 2011) }\end{array}$ \\
\hline F16 & Near to Education & $\begin{array}{l}\text { (Clark } \text { et al., 2006; Mulliner \& Maliene, 2011; } \\
\text { Samuels, 2004) }\end{array}$ \\
\hline F17 & Near to Workplace & (King, 2008; Mulliner \& Maliene, 2011) \\
\hline F18 & Environment Quality & (Cowan \& Hill, 2005; Zhu et al., 2006) \\
\hline F19 & Security & (Hipp, 2010; Samuels, 2004) \\
\hline F20 & Traffic Congestion & (Brownstone \& Golob, 2009; Shen et al., 2011) \\
\hline F21 & Density & (Brownstone \& Golob, 2009; Samuels, 2004) \\
\hline F22 & View & (Zhu et al., 2006) \\
\hline F23 & Exterior Condition & (Said et. al, 2016) \\
\hline F24 & Availability of Waste Management & $\begin{array}{l}\text { (Hardi \& Zidan, 1997; Joseph, 2006; Mulliner \& } \\
\text { Maliene, 2011) }\end{array}$ \\
\hline F25 & Safety Level & (Hipp, 2010; Samuels, 2004) \\
\hline F26 & Theme or Concept & (Said et. al, 2016) \\
\hline & & \\
\hline
\end{tabular}




\subsection{Measuring Sustainable Housing Affordability}

The assessment of the effectiveness of sustainability application can be a daunting task. Mulliner and Maliene (2011) propose a set of criteria and use a multi-criteria decision making (MCDM) technique to assess and rank the said criteria in determining the sustainable housing affordability (Mulliner et al., 2013). Some researchers assess sustainable housing affordability by focussing on the strengths and weaknesses of various criteria or factors (Hak et al., 2012; Hardi \& Zidan, 1997; Mori \& Christodoulou, 2012; Toman et al.,1998). In addition, most housing economists focus on housing price rather than holistic measures of the condition, locational attributes and neighbourhood characteristics (Bogdon \& Can, 1997).

In the built environment, a Complex Proportional Assessment (COPRAS) method can be applied to the varieties of research. COPRAS is used as a tool to assess sustainable housing affordability based on factors or criteria systems. The method is suitable for cases where data are expressed in interval forms (Popović et al. ,2012) and used to determine the priority and the utility degree of alternatives (Zavadskas \& Kaklauskas, 1996; Zavadskas et al., 2008).

COPRAS is one of the many MCDM techniques. MCDM has gained wide acceptance throughout different sectors due to its effectiveness and simple process. The technique is particularly useful in making a highly complex decision by applying weight or priorities (Aruldoss et al. (2013), involving a careful selection of resources to ensure the accuracy of criteria, alternatives or factors (Haarstrick \& Lazarevska, 2009).

\section{METHODOLOGY}

Malaysia sits within the region of South East Asia and is made up of Peninsular Malaysia (West Malaysia) and East Malaysia (comprising Sabah and Sarawak). Because of population factor, housing development is currently more vigorous in West Malaysia than in East Malaysia. Sarawak is bordered by Sabah to the northeast and Kalimantan to the south and Brunei in the north. Its capital city, Kuching, was chosen as the geographical area of this study. Kuching is the economic centre and the most populous city in the state thus representing the most active area for housing development in Sarawak. It is the only city in Malaysia to be split into two - Kuching Utara and Kuching Selatan - each administered by its own mayor. In the city, the existing urbanisation process continues further, resulting in demand for housing.

The questionnaires were distributed to residents in both Kuching Utara and Kuching Selatan and surrounding areas including Samarahan which is administered by the Majlis Daerah Samarahan and Batu Kawa. These surrounding areas are categorised as others in the analysis. Table 2 shows the total population of key areas of study.

Table 2: Population by Local Authority Areas (2010)

\begin{tabular}{|l|l|l|}
\hline Area & Local administration & Total population \\
\hline Kuching Utara & Dewan Bandaraya Kuching Utara & 165,642 \\
\hline Kuching Selatan & Majlis Bandaraya Kuching Selatan & 159,490 \\
\hline Samarahan & Majlis Daerah Samarahan & 87,923 \\
\hline
\end{tabular}

Source: Department of Statistics Malaysia (2012)

The respondents must be from owneroccupied properties or the main renters (head lessor) in the study areas. They are considered as the stakeholders of the affordable units in the study area. Those not belonging to either of the two would be disqualified and terminated from further interview. The purpose of the questionnaires is to verify and elicit respondents' opinion on what criteria constitute sustainable housing affordability. Out of 600 distributed questionnaires, 471 were answered by valid respondents of which $55 \%$ were from
Kuching Utara, 27\% from Kuching Selatan and $18 \%$ from other nearby areas (Others).

The total of 26 criteria is considered to be relevant in assessing sustainable housing affordability (Table 3). Respondents distinguish each criterion based on its relative importance towards sustainable housing affordability. Responses are ranked on a five-point Likert Scale. Likert scale was used because of its simplicity in expressing respondents' level of agreement (Allen et al., 2007). 
Table 3: Criteria for Sustainable Housing Affordability

\begin{tabular}{|l|l|}
\hline No. & Criteria \\
\hline 1 & Housing Price \\
\hline 2 & Housing Type \\
\hline 3 & Housing Finishes \\
\hline 4 & Housing Design \\
\hline 5 & Position of the unit in Layout Plan \\
\hline 6 & Size of Built-up Area \\
\hline 7 & Size of Land Area \\
\hline 8 & Age of the Unit \\
\hline 9 & Topography \\
\hline 10 & Property Interest \\
\hline 11 & Near to Commercial Area \\
\hline 12 & Near to Hospitals \\
\hline 13 & Near to Post Office \\
\hline 14 & Near to Recreation Area \& Public Space \\
\hline 15 & Near to Transportation \\
\hline 16 & Near to Education \\
\hline 17 & Near to Workplace \\
\hline 18 & Environmental Quality \\
\hline 19 & Security \\
\hline 20 & Traffic Congestion \\
\hline 21 & Density \\
\hline 22 & View \\
\hline & Exterior Condition \\
\hline 26 & Availability Waste Management \\
\hline & Safety Level \\
\hline & Theme or Concept \\
\hline
\end{tabular}

\subsection{Assessment of Sustainable Housing}

\section{Affordability}

The data was analysed using COPRAS method involving five main steps (Kaklauskas et al., 2005, 2007 ${ }_{\mathrm{a} \& \mathrm{~b}}$; Dey et al., 2011; Mulliner et al., 2013).

1. The listing and selection of various criteria and the normalisation of the decisionmaking matrix. The main purpose is to assess sustainable housing affordability in the chosen areas to create a ranking of alternatives. COPRAS can handle such problem involving both positive and negative factors that influence the decision making. The following formula is used by taking the overall mean score to allow direct comparison between all factors:

$$
m_{p q}=\frac{\overline{\mathrm{w}}_{p q}}{\sum_{q=1}^{n} x_{p q}} x_{p q}
$$

Where $\mathrm{x}_{\mathrm{pq}}$ is the value of the $p$-th criterion of the $q$-th options, and $\overline{\mathrm{w}}_{\mathrm{p}}$ is the weight of the $p$-th criterion.

Table 4 shows the overall mean score for the identified criteria. The highest score went to the 'house price', followed by 'the safety level of development area', which is the second most important criteria. The least important criteria go to 'the theme or concept of development' where most respondents did not find it significant as compared to the rest of the criteria

Table 4: Overall mean score and the weight of each criterion

\begin{tabular}{|l|c|c|}
\hline Factors/Characteristics & N & Mean Score (overall) \\
\hline House Price & 470 & 4.4149 \\
\hline House Type & 469 & 4.1130 \\
\hline House Finishes & 469 & 3.9616 \\
\hline House Design & 469 & 3.9616 \\
\hline Position House in Layout Plan & 468 & 3.9658 \\
\hline Size of Built-up Area & 469 & 4.0341 \\
\hline
\end{tabular}




\begin{tabular}{|l|l|l|}
\hline Size of Land Area & 469 & 4.0362 \\
\hline Age of the House & 468 & 4.0363 \\
\hline Topography & 469 & 3.9339 \\
\hline Property Interest & 463 & 3.9309 \\
\hline Near to Commercial Area & 468 & 3.9915 \\
\hline Near to Hospitals & 468 & 4.0769 \\
\hline Near to Post Office & 468 & 3.9124 \\
\hline Near to Recreation Area, Public Space & 468 & 3.9487 \\
\hline Near to Transportation & 468 & 4.0171 \\
\hline Near to Education & 467 & 4.0921 \\
\hline Near to Workplace & 466 & 4.1760 \\
\hline Environmental Quality & 467 & 4.1242 \\
\hline Security & 468 & 4.1111 \\
\hline Traffic Congestion & 468 & 4.0769 \\
\hline Density & 468 & 4.1410 \\
\hline View & 468 & 3.9402 \\
\hline Exterior Condition & 467 & 4.0664 \\
\hline Availability of Waste Management & 468 & 4.0427 \\
\hline Safety Level & 468 & 4.2073 \\
\hline Theme or Concept & 468 & 3.8868 \\
\hline
\end{tabular}

Table 5 derives the relative weight for each factor, $\bar{w}$ and an individual mean score of each alternative area, which is essential for the next step of using the COPRAS method.

Table 5: The weight and means score for each alternative area

\begin{tabular}{|l|c|c|c|c|}
\hline Criteria & Weight, q & Kuching Utara & Kuching Selatan & Others \\
\hline Housing Price & 2.521 & 4.4218 & 4.4732 & 4.3133 \\
\hline Housing Type & 2.349 & 4.1423 & 4.0268 & 4.1325 \\
\hline Housing Finishes & 2.262 & 3.9453 & 4.0625 & 3.8795 \\
\hline Housing Design & 2.262 & 3.9526 & 3.9821 & 3.9639 \\
\hline Position of the unit in Layout Plan & 2.265 & 3.9158 & 4.0268 & 4.0482 \\
\hline Size of Built-up Area & 2.304 & 4.0219 & 4.0625 & 4.0361 \\
\hline Size of Land Area & 2.305 & 4.0438 & 4.0446 & 4.0000 \\
\hline Age of the Unit & 2.305 & 3.9927 & 4.0901 & 4.1084 \\
\hline Topography & 2.247 & 3.8723 & 4.0446 & 3.9880 \\
\hline Property Interest & 2.245 & 3.9081 & 4.0275 & 3.8780 \\
\hline Near to Commercial Area & 2.279 & 3.9963 & 4.0625 & 3.8795 \\
\hline Near to Hospitals & 2.328 & 4.0842 & 4.1071 & 4.0120 \\
\hline Near to Post Office & 2.234 & 3.9377 & 3.9911 & 3.7229 \\
\hline Near to Recreation Area, Public Space & 2.255 & 3.9707 & 4.0357 & 3.7590 \\
\hline Near to Transportation & 2.294 & 4.0476 & 4.0625 & 3.8554 \\
\hline Near to Education & 2.337 & 4.1471 & 4.1071 & 3.8916 \\
\hline Near to Workplace & 2.385 & 4.2206 & 4.1429 & 4.0732 \\
\hline Environmental Quality & 2.355 & 4.1103 & 4.2054 & 4.0602 \\
\hline Security & 2.348 & 4.1538 & 4.1429 & 3.9277 \\
\hline Traffic Congestion & 2.328 & 4.0806 & 4.0893 & 4.0482 \\
\hline Density & 2.365 & 4.0769 & 4.5089 & 3.8554 \\
\hline View & 2.250 & 3.9560 & 4.0625 & 3.7229 \\
\hline Exterior Condition & 2.322 & 4.1287 & 4.0536 & 3.8795 \\
\hline Availability of Waste Management & 2.309 & 4.0330 & 4.0982 & 4.0000 \\
\hline Safety Level & 2.403 & 4.2454 & 4.1875 & 4.1084 \\
\hline Theme or Concept & 2.220 & 3.9158 & 4.0446 & 3.5783 \\
\hline
\end{tabular}

2. The weight is summarised to normalise the decision-making matrix by calculating the sums of both positive and negative alternatives
(Table 6). The sums of $S_{+q}$ of attributes values which provide larger values are preferable (the direction of optimisation and maximisation) as 
compared to other alternatives. The sums of $S_{-q}$ of attributes values which constitute smaller values are preferable (the direction of optimisation and minimisation) as compared to other alternatives. For example, the lower the negative (minimisation) values for the house price, the better the sustainable housing affordability is. Likewise, the higher the positive (maximisation) values, the better it indicates. The formula to calculate the sums are as follows:

$$
\begin{aligned}
& S_{q}^{+}=\sum_{e_{p}=+} m_{p q} \\
& S_{q}^{-}=\sum_{e_{p}=-} m_{p q}
\end{aligned}
$$

Table 6 represents the normalised decision matrix for the three chosen areas in Kuching namely Kuching Utara, Kuching Selatan and other surrounding areas.

\begin{tabular}{|c|c|c|c|c|}
\hline Factors/Characteristics & $\mathbf{Z}$ & Kuching Utara & $\begin{array}{l}\text { Kuching } \\
\text { Selatan }\end{array}$ & Others \\
\hline House Price & - & 0.844 & 0.854 & 0.823 \\
\hline House Type & + & 0.791 & 0.769 & 0.789 \\
\hline House Finishes & + & 0.751 & 0.773 & 0.738 \\
\hline House Design & + & 0.751 & 0.757 & 0.754 \\
\hline $\begin{array}{l}\text { Position House in Layout } \\
\text { Plan }\end{array}$ & + & 0.740 & 0.761 & 0.765 \\
\hline Size of Built-up Area & + & 0.765 & 0.772 & 0.767 \\
\hline Size of Land Area & + & 0.771 & 0.771 & 0.763 \\
\hline Age of the House & - & 0.755 & 0.773 & 0.777 \\
\hline Topography & - & 0.731 & 0.763 & 0.753 \\
\hline Property Interest & - & 0.743 & 0.765 & 0.737 \\
\hline Near to Commercial Area & - & 0.763 & 0.776 & 0.741 \\
\hline Near to Hospitals & - & 0.779 & 0.784 & 0.765 \\
\hline Near to Post Office & - & 0.755 & 0.765 & 0.714 \\
\hline $\begin{array}{l}\text { Near to Recreation Area, } \\
\text { Public Space }\end{array}$ & - & 0.761 & 0.773 & 0.720 \\
\hline Near to Transportation & - & 0.776 & 0.779 & 0.739 \\
\hline Near to Education & - & 0.798 & 0.790 & 0.749 \\
\hline Near to Workplace & - & 0.809 & 0.794 & 0.781 \\
\hline Environmental Quality & + & 0.782 & 0.800 & 0.773 \\
\hline Security & + & 0.798 & 0.796 & 0.754 \\
\hline Traffic Congestion & - & 0.778 & 0.779 & 0.771 \\
\hline Density & - & 0.775 & 0.857 & 0.733 \\
\hline View & + & 0.758 & 0.778 & 0.713 \\
\hline Exterior Condition & + & 0.795 & 0.780 & 0.747 \\
\hline $\begin{array}{l}\text { Availability of Waste } \\
\text { Management }\end{array}$ & + & 0.768 & 0.780 & 0.761 \\
\hline Safety Level & + & 0.813 & 0.802 & 0.787 \\
\hline Theme or Concept & + & 0.753 & 0.778 & 0.688 \\
\hline
\end{tabular}

Table 6: Normalized decision matrix by alternative area

3. The relative significance $H_{q}$ of each option, based on positive (+) and negative (-), is calculated using the formula below:

$$
H_{q}=S_{q}^{+}+\frac{S_{\min }^{-} \sum_{q=1}^{n} S_{q}^{-}}{S_{q}^{-} \sum_{q=1}^{n} \frac{S_{\min }^{-}}{S_{q}^{-}}}=S_{q}^{+}+\frac{\sum_{q=1}^{n} S_{q}^{-}}{S_{q}^{-} \sum_{q=1}^{n} \frac{1}{S_{q}^{-}}}
$$

where the minimum values $\mathrm{S}_{\mathrm{q}}{ }^{-}$are cancelled, the higher value corresponds to a more sustainable housing affordability.

4. In this stage, prioritisation is determined by the largest $H_{q} . H_{\max }$ is the optimal value and the best among alternatives. Options are ranked from highest to lowest of relative significance $H_{q}$. 
5. The degree of utility is determined by comparing each option by the one option with $H_{\max }$. The area with the highest level of utility degree $\left(\breve{\mathrm{u}}_{\mathrm{q}}=100 \%\right)$ represents an area that most satisfies sustainable housing affordability. Other options will show utility values ranging from $0 \%-100 \%$ indicators of the worst to the best-case scenario (Table 7). The degree of utility $\breve{\mathrm{u}}_{\mathrm{q}}$ of the options $O_{q}$ is calculated by the following formula:

$$
\check{\mathrm{u}}_{u}=\frac{H_{q}}{H_{\max }} 100 \%
$$

\section{RESULTS \& DISCUSSION}

\subsection{Demographic}

Figure 1 shows the distribution of respondents in the study area (471 valid respondents). The majority of the valid respondents come from the area of Kuching Utara (55\%), followed by Kuching Selatan (27\%). As discussed, other areas (Others) represent respondents within the same locality but outside the two municipalities. It represents the smallest amount of the valid respondents $(15 \%)$.

Figure 1: Distribution of valid respondents in the study area

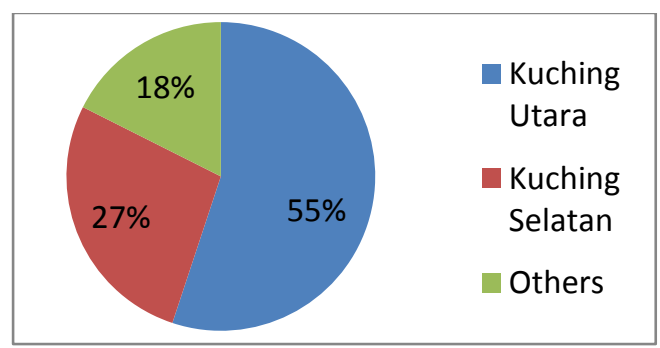

Figure 2 depicts the house ownership of respondents (either owner occupiers or renters). Out of the total valid respondents, $35.6 \%$ of them declared to be house owners whereas $64 \%$ are renters. Across the alternative areas,
Kuching Utara recorded the number of respondents who are owner-occupiers or renters $30.1 \%$ and $69.9 \%$ respectively. Kuching Selatan also recorded more renters than house owners at $71.1 \%$ and $28.3 \%$ respectively. However, other areas (Others) recorded more owner-occupiers as compared to renters at $63.9 \%$ and $36.1 \%$ respectively.

Figure 2: Housing ownership in the study area

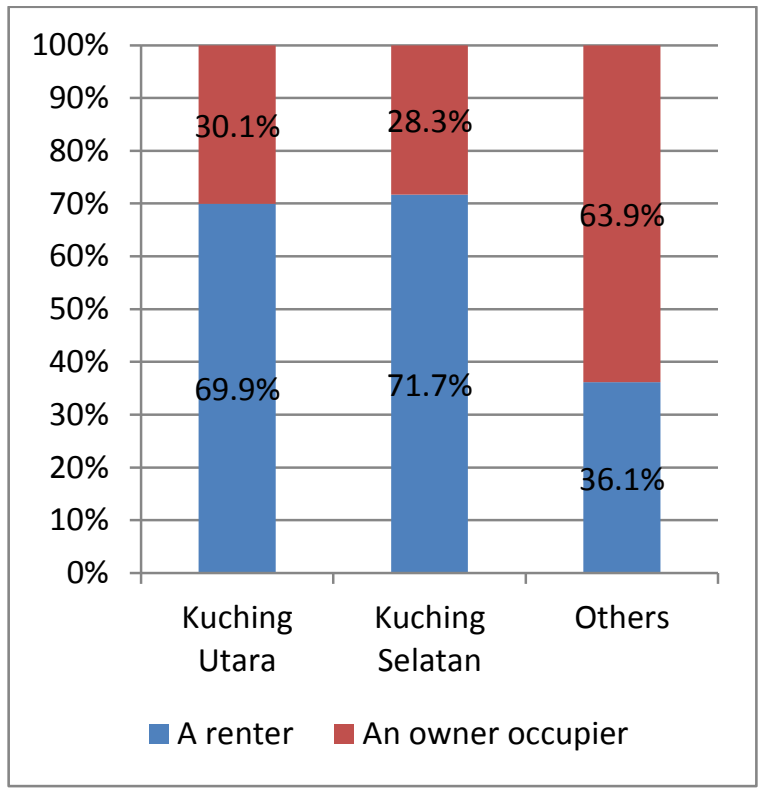

Figure 3 shows the monthly household income by area. The result indicates that Kuching Utara recorded the highest proportion of respondents with a monthly household income of less than RM1,500 at $19.2 \%$ as compared to Kuching Selatan at $11.5 \%$ and Others at $13.5 \%$. Respondents in Kuching Selatan represent the majority who earned between RM 1,501 RM2,500 (31.9\%) as compared to other areas. There is an almost equal share of respondents who earned between RM2,501-RM3,500 across all alternative areas. Interestingly, Kuching Selatan represents the majority of respondents (11.5\%) who earned more than RM 8,501

Figure 3: Monthly household income of respondents by alternative area 


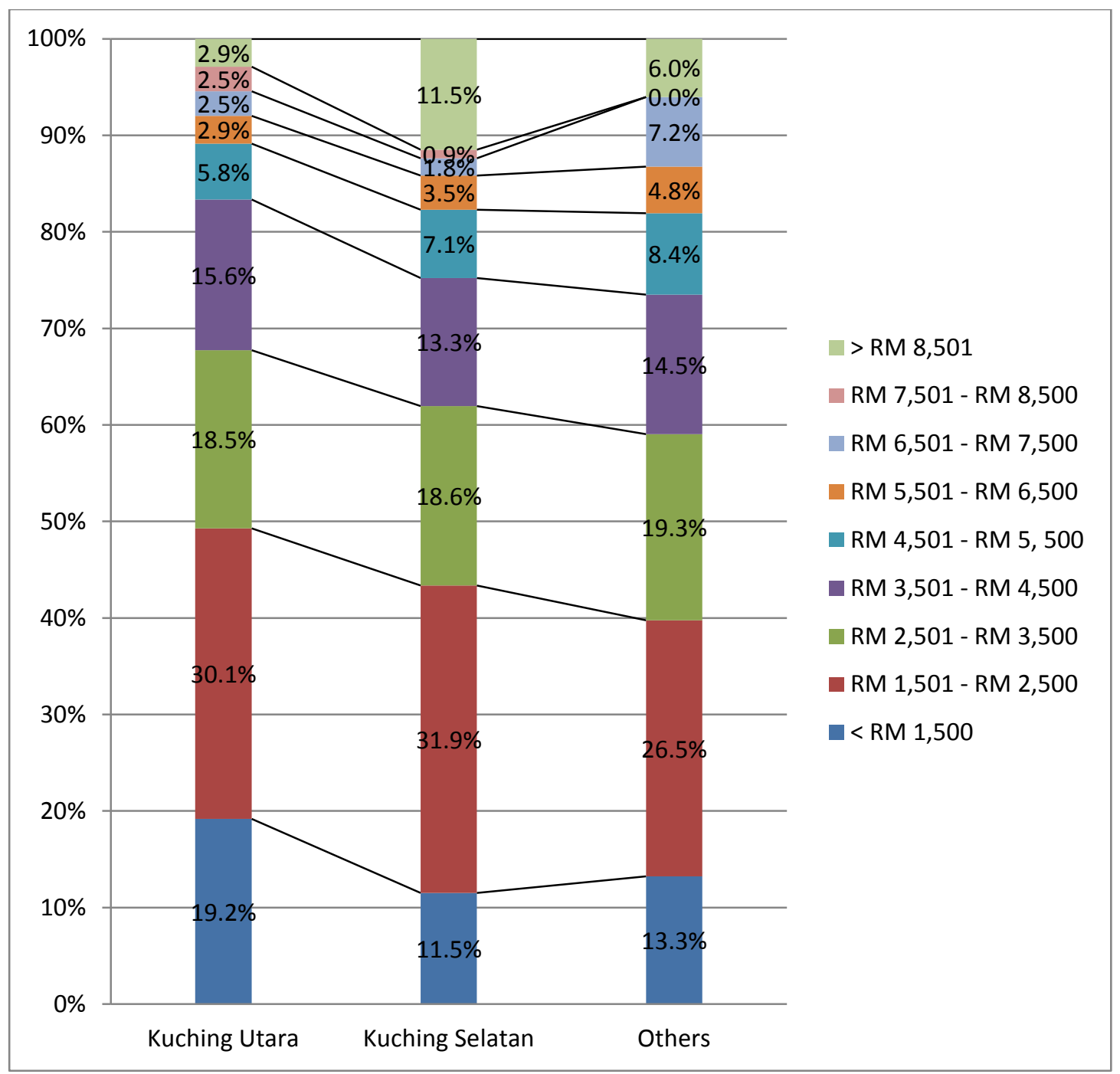

\subsection{Sustainable Housing Affordability}

The step-by-step procedure in COPRAS assessment (Section 3.1) produces the following results (Table 7).

Table 7: Sustainable Housing Affordability Factors

\begin{tabular}{|c|c|c|c|}
\hline & $\begin{array}{c}\text { Kuching } \\
\text { Utara }\end{array}$ & $\begin{array}{c}\text { Kuching } \\
\text { Selatan }\end{array}$ & Others \\
\hline $\mathrm{S}+$ & 18.005 & 18.140 & 17.135 \\
\hline $\mathrm{S}-$ & 15.343 & 15.885 & 15.492 \\
\hline $\mathrm{H}$ & 33.809 & 33.405 & 32.787 \\
\hline Priority & 1 & 2 & 3 \\
\hline ǔ(\%) & $100.00 \%$ & $98.81 \%$ & $96.98 \%$ \\
\hline
\end{tabular}

Table 7 shows the best performing area in relation to the predetermined factors of sustainable housing affordability. Therefore, the location that best describes the most sustainable housing affordability is Kuching Utara as reflected in utility degree of $100 \%$. The second-best area is Kuching Selatan with a utility degree of $98.81 \%$. The lowest rank is other areas (Others) with a utility degree of $96.98 \%$. The results also show that the the greatest concerns in Kuching are house price as well as other factors such as safety level and proximity to workplace (Table 6). Surprisingly, the respondents are not very sensitive to development theme or concept and the position of the unit in the layout plan.

Each of the three areas has almost equal utility degrees of between $97 \%$ to $100 \%$. Evidence shows that the difference between the best option (Kuching Utara) and the worst (Others) is miniscule at $3.0 \%$. This could be translated into layman terms as the advantages 
and disadvantages of both areas being almost equal and often interchangeable with one another, other factors offset thus the demand for housing is unintelligible. In other words, Kuching Utara proved to be sustainable in terms of housing affordability, and it is the best area to stay as compared to the rest of the alternatives. However, vast improvement can be done in the analysis by focusing on a smaller area, i.e. by zoning, precinct or section within the larger area. Therefore, COPRAS method has substantially demonstrated its effectiveness in assessing the sustainability of different areas by providing the utility degree of options. Its flexibility could be applied to any region and place, and the weight can be adjusted to suit any context.

\section{CONCLUSION}

Under the present market condition, the increasing value or rent of the housing unit coupled with the rising cost of living force people to find the best alternative area to live. Those on higher income would consider several factors in making their purchase or investment decision. Those who cannot afford to purchase would also consider factors that affect their monthly budget in determining the best area to stay. Over time, price and household income become paramount to their decision. Therefore, a wise purchaser or renter would consider the three sustainability factors namely social, economic and environment. Such consideration would force the market to discriminate in order to find the best alternative area to stay. This will become the most important decision to individual and/or society.

This paper has adequately demonstrated the necessity to shift from the common priceincome-cost genre towards sustainabilityquality-affordability value. The main concern of any government is to provide housing units that are affordable to their citizen. However, such concern cannot be solved individually by market players. Therefore, cooperation between all market players is crucial in providing housing units that are affordable to most people. The cooperation would help the market players to consider the relevance of factors that can sustain the affordable housing units rather than simply a housing cost. The government through its local authorities could adopt the same analysis for a proper planning of urban dwellings. Other market players such as property developers may utilise the results to find the best area to improve their future housing development. This would prove beneficial to all the market players including the purchasers or renters. The results and method could also be used by the housing purchasers or renters in deciding the best area to buy or rent in fulfilling their preferences.

\section{ACKNOWLEDGEMENT}

The authors would like to acknowledge with gratitude the funding received from the University of Malaya Research Grant (UMRG) for this research (Project No. RP007E-13SUS).

\section{REFERENCES}

Abidin, Z.N. (2010). Investigating the awareness and application of sustainable construction concept by Malaysian developers. Habitat International, 34, 421426.

Allen, I. Elaine, and Christopher A. Seaman (2007), "Likert Scales and Data Analyses." Quality Progress.

Ankhi, B. \& Joy, S. (2013), A Study on Housing Affordability in Kolkata Urban Agglomeration (KUA), Based on Infrastructure Driven Housing Price Distribution and Household IncomeExpenditure Pattern, International Journal of Property Sciences, 3:1, pp 1-20.

Aruldoss, M., Lakshmi, T. M., \& Venkatesan, V. P. (2013). A survey on multi-criteria decision-making methods and its applications. American Journal of Information Systems, 1(1), 31-43.

Australian Conservation Foundation. (2008). housing affordability: more than just mortgage and rent: Australian Conservation Foundation and the Victorian Council of Social Service.

Aziz, W. N. A. W. A., Hanif, N. R., \& Singaravello, K. (2010). Housing Affordability Issues For Middle Income Households: the Malaysian perspective. Paper presented at the ENHR Istanbul: Istanbul Technical University.

Beck, M. B., \& Cummings, R. (1996). Wastewater Infrastructure: Challenges for the Sustainable City in the New Millennium. Habitat International, 20, 405-420.

Bogdon, A. S., \& Can, A. (1997). Indicators of local housing affordability: Comparative and spatial approaches. Real Estate Economics, 25(1), 43-80. doi: 10.1111/1540-6229.00707

Brownstone, D., \& Golob, T. F. (2009). The impact of residential density on vehicle usage and energy consumption. Journal of urban Economics, 65, 91-98. 
Brundtland, G. H. (1996), Our common future revisited, Brown Journal of World Affairs, III(2), 175.

Burke, T., Pinnegar, S., Phibbs, P., Neske, C., Gabriel, M., \& Ralston, L. (2007). Experiencing the housing affordability problem: blocked aspirations, trade-offs and financial hardships National Research Venture 3: Housing affordability for lower income Australians (Vol. 9): Australian Housing and Urban Research Institute.

Clark, W., Deurloo, M., \& Dieleman, F. (2006). Residential Mobility and Neighbourhood outcomes. Housing Studies, 21, 323-342.

Cowan, R., \& Hill, D. (2005). Start with the Park Creating sustainable urban green spaces in areas of housing growth and renewal. Commission for Architecture \& the Built Environment (CABE).

Department of Statitics (2012). Household Income and Basic Amenities Survey Report 2012

Dey, P. K., Ghosh, D. N., \& Mondal, A. C. (2011). A MCDM approach for evaluating bowlers performance in IPL. Journal of Emerging Trends in Computing and Information Sciences, 2(11), 563-573.

Drexhage, J., \& Murphy, D. (2010). Sustainable Development: From Brundtland to Rio 2012.

Fierro, K., Fullerton, T., \& Donuan-Callejo, K. (2009). Housing attribute preference in a northern Mexico metropolitan economy. Atlantic Economic Journal, 37, 159-172.

Haarstrick, A., \& Lazarevska, A. (2009). MultiCriteria Decision Making (MCDM)- A conceptual Approach to Optimal Landfill Monitoring Paper presented at the 3rd International Workshop "Hydro-PysicoMechanics of Landfills", Braunschweig, Germany.

Hak, T., Kovanda, J., \& Weinzettel, J. (2012). A method to assess the relevance of sustainability indicators: application to the indicator set of the Czech Republic's Sustainable Development Strategy. Ecological Indicators, 17, 46-57.

Hardi, P., \& Zidan, T. (1997). Assessing sustainable development: Principles in practice. Canada: International Institute for Sustainable Development.

Hipp, J. (2010). What is the 'neighbourhood' in neighbourhood satisfaction? Comparing the effects of structural characteristics measured at the micro neighbourhood and trace levels. Urban Studies, 47, 2517-2536.

Hurtubia, R., Gallay, O., \& Bierlaire, M. (2010). Attributes of households, locations and real estate markets for land use modelling. Sustain City Working Paper, 2.7, EPFL, Lausanne.

Iman, A. H. M. (2006). Property Demand and Supply. Skudai: UTM Publisher.

Isalou, A. A., Litman, T., \& Shahmoradi, B. (2014). Testing the housing and transportation affordability index in a developing world context: A Sustainability comparison of central and suburban districts in Qom, Iran. Transport policy, 33, 33-39.

Islam, N. (1996). Sustainability Issues in Urban Housing in a Low-income Country: Bangladesh. Habitat International, 20, 377288.

Joseph, K. (2006). Stakeholder participation for sustainable waste management. Habitat International, 30, 863-871.

Kaklauskas, A., Zavadskas, E. K., Banaitis, A., \& Satkauskas, G. (2007a). Defining the utility and market value of a real estate: a multiple criteria approach. International Journal of Strategic Property Management, 11(2), 107-120.

Kaklauskas, A., Zavadskas, E. K., \& Raslanas, S. (2005). Multivariant design and multiple criteria analysis of building refurbishments. Energy and Buildings, 37, 361-372.

Kaklauskas, A., Zavadskasb, E. K., \& Trinkunasa, V. (2007b). A multiple criteria decision support on-line system for construction. Engineering Applications of Artificial Intelligence, 163-175.

Kates, R. W., Parris, T. M., \& Leiserowitz, A. A. (2005). What is Sustainable Development? Goals, Indicators, Values and Practice. Environment: Science and Policy for Sustainable Development, 47, 8-21.

Kibert, C. J. (2004). Green building: An overview of progress. Journal of Land Use \& Environmental Law, 19(2), 491-502.

King, L. A. (2008). Sustainable Community Development Code: Housing Affordability. Arlington, Virginia: Housing Food System.

Lu, M. (2002). Are Pastures Greener? Residential consequence of migration. International Journal of Population Geography, 8, 201-216.

Majid, R.A. and Said, R. (2013), Impak Kitaran Hartanah Dalam Pasaran Perumahan, Journal of Design and Built Environment, Vol 12, pp 1-9.

Maliene, V., \& Malys, N. (2009). High quality housing- A key issue in delivering sustainable communities. Journal of Building and environment, 44, 426-430.

Mcalpine, P., \& Birnie, A. (2007). Is there a correct way of establishing sustainability indicators? The case of sustainability indicator development on the Island of 
Guernsey. Local Environment: The International Journal of Justice and Sustainability, 10(3), 243-257.

Medineckiene, M., Turskis, Z., \& Zavadskas, E. K. $\left(2010_{\mathrm{a}}\right)$. Sustainable construction taking into account the building impact on the environment. Journal of Environmental Engineering and Landscape Management, 18(2), 118-127. doi: http://dx.doi.org/10.3846/jeelm.2010.14

Medineckienè, M., Turskis, Z., Zavadskas, E. K., \& Tamošaitienè, J. (2010 $\left.\mathrm{b}_{\mathrm{b}}\right)$. MultiCriteria Selection Of The One Flat Dwelling House, Taking Into Account The Construction Impact On Environment Paper presented at the The 10th International Conference, Vilnius, Lithuania.

Mohamad, W.S.W.M. \& Ahmad, Y. (2016), Sustainability in Self Build Housing in Rural Area of Kedah, Malaysia, International Journal of Property Sciences, 6:1, pp 50-59.

Morgan, J., \& Talbot, R. (2001). Sustainable social housing for no extra cost? $\mathrm{K}$. in Williams, Burton, E. \& Jenks, M. (Ed.) Achieving sustainable urban form (pp. 319328).

Mori, K., \& Christodoulou, A. (2012). Review of sustainability indices and indicators: Towards a new City Sustainability Index (CSI). Environmental Impact Assessment Review, 32, 94-106.

Mulliner, E., \& Maliene, V. (2011). Criteria for sustainable housing affordability. Journal of Environmental Engineering, 3, 966-973.

Mulliner, E., Smallbone, K., \& Maliene, V. (2013). An assessment of sustainable housing affordability using a multiple criteria decision making method. OmegaInternational Journal of Management Science, $41(2), \quad 270-279 . \quad$ doi: 10.1016/j.omega.2012.05.002

Othman, K. N., \& Alias, A. (2011). The effects of property laws and regulations towards sustainable property development in Malaysia: A preliminary review. Paper presented at the International Conference on Project and Facilities Management, Kuala Lumpur.

Payne, D., \& Raiborn, C. (2001). Sustainable development: the ethics support the economics. Journal of Business Ethics, 32(2), 157-168.

Popović, G., Stanujkić, D., \& Stojanović, S. (2012). Investment projects selection by applying copras method and imprecise data. Serbian Journal of Management, 7(2), 2570269 .
Pullen, S., Arman, M., Zillante, G., Zuo, J., Chileshe, N., \& Wilson, L. (2010). Developing an Assessment Framework for Affordable and Sustainable Housing. Australasian Journal of Construction Economics and Building, 10(1/2), 48-64.

Said, R., Majid, RA., Alias, A., Adnan, Y.M. \& Razali, M.N. (2016), Sustainable Housing Affordability in Sabah, Planning Malaysia: Journal of the Malaysian Institute of Planners, Special Issue V, pp 65 -76.

Samuels, I. (2004). What home buyers want: attitudes and decision-making among home buyers. In Mulholland Research and Consulting (Ed.). London: Commission for Architecture \& the Built Environment.

Saunders, P. (1990). A Nation of Home Owners. London: Unwin Hyman.

Shen, L.-Y., Ochoa, J. J., Shah, M. N., \& Zhang, X. (2011). The application of urban sustainability indicators- A comparison between various practices. Habitat International, 35, 17-29.

Toman, M. A., Lile, R., \& King, D. (1998). Assessing sustainability: some conceptual and empirical challenges. Discussion Paper 98-42.

Turcu, C. (2012). Local experiences of urban sustainability: Researching housing market renewal interventions in three english neighbourhoods. Progress in Planning, 78, 101-150.

Van Vliet, W. (1996). Sustainable Development, Global Restructuring and Immigrant Housing. Habitat International, 20, 349-358.

Yates, J. (2008). Australia's housing affordability crisis. Australian Economic Review, 41(2), 200-214. doi: 10.1111/j.1467-8462.2008.00502.x

Yusuf, A., \& Resosurdarmo, B. (2009). Does clean air matter in developing countries' megacities? A hedonic price analysis of the Jakarta Housing Market, Indonesia. Ecological Economics, 66, 1398-1407.

Zavadskas, E. K., \& Kaklauskas, A. (1996). Multiple criteria evaluation of buildings. Vilnius, Lithuania.

Zavadskas, E. K., Kaklauskas, A., Turskis, Z., , \& Tamosaintinei, J. (2008). Multi-Attribute Decision-Making Model by Applying Grey Numbers. Institute of Mathematics and Informatics, 20(2), 305-320.

Zhu, X., Liu, S., \& Yeow, M.-C. (2006). Accessibility analysis for housing development in Singapore with GIS and multi-criteria analysis methods. Applied GIS, 2(2), 13.11-13.12. 
Zyed, Z.A.S., Aziz, W.N.Z. \& Hanif, N.R. (2016), Housing Affordability Problems among Young Households, Journal of
Surveying, Construction and Property, 7:1, pp 1-18. 